\title{
Identification of Coffee Fruit Consumption Based Mongoose Age
}

\author{
Ifmalinda \\ Faculty of Agricultural Technology Andalas University, West Sumatera, 25163, Indonesia \\ E-mail:ifmalinda_1273@yahoo.com
}

\begin{abstract}
Methods of captive breeding of civet coffee is one solution to increase the production of civet coffee. The principle of the welfare of animals used in this study is based on a five (5) the principle of freedom of animals (five freedom) which is applied as a minimum standard of animal welfare, the animal mongoose are involved in the production system civet coffee must be guaranteed well-being by applying the principles of animal welfare include: free from hunger and thirst; freedom from pain, injury and disease; freedom from discomfort, mistreatment, and abuse; free from fear and distress; and free to express their natural behavior. The survey results into captivity writer Pangalengan mongoose in Bandung, age mongoose kept ranging between 1-4 years and male and female. In the case of feeding the coffee fruit, maintainer civet civet usually gives to each weighing about $3 \mathrm{~kg}$ feed. The amount of feed given is not all consumed mongoose. Until now there has been no regulation or standard amount of feed weight by age mongoose. The research aims to determine the amount of feed weight based age civet coffee fruit. The method used was completely randomized factorial design with 3 levels of treatment. The treatment of the first stage was the color of coffee cherries (W) consisting of 3 levels: the coffee fruit yellow (w1), red coffee cherries (w2) and blackish red coffee berries (w3). Treatment level to 2 is gender civet (K) consisting of two levels: male mongoose (k1) and female mongoose (k2). Treatment level to 3 is the lifespan of civet (U) consists of 2 levels were age 1-2 (u1) years and the age of 3-4 years (u2).The results showed no difference in the level of consumption of red fruit for civet coffee 2 years old and 4 years old mongoose namely the age of 4 years (771.67) $\mathrm{g}$ higher than 2 years old mongoose (642.94) g. Differences in the level of consumption of coffee berries are dark red to civet age 2 years and 4 years old mongoose mongoose ie 4 years of age (1183.50) g higher than the age of 2 years mongoose (668.89) g. Age 2 years the level of consumption of civet coffee berries are red and dark red there is no difference. The level of consumption of civet age of 4 years for coffee cherries red and dark red there is a difference, namely civet 4 years old consume more coffee berries are dark red.
\end{abstract}

Keywords - civet coffee; consumption of civet; age mongoose; mongoose; coffee

\section{INTRODUCTION}

Coffee is one of the leading commodity in the plantation sub-sector in Indonesia because it has market opportunities both domestically and abroad. Most of the coffee production in Indonesia are commodities that are sold to the world market. The main destination countries of Indonesian coffee exports are the United States, Germany and Japan [1].

Currently on the market encountered the kind of coffee that has a high price civet coffee. Civet coffee prices in Japan and South Korea as well as a number of other countries reached 2 millions $/ \mathrm{kg}$ or even more, in Indonesia cost about one millions $/ \mathrm{kg}$ [2]. Civet coffee is arabica and robusta coffee beans are eaten, are processed through the digestive system and issued with coffee beans civet dung. Before being processed into civet coffee, coffee beans are cleaned, dried by the sun and ground into powder civet coffee. The origin of civet coffee is closely linked with the history of coffee cultivation in Indonesia. In the Dutch colonial era, land clearing for cultivation of coffee in nearly all parts of Indonesia. One is the Arabica coffee seedlings imported from Yemen. Ironically farmer workers may not take the coffee harvest. Then around the 19th century in
Central Java, plantation workers find feces or dirt mongoose around coffee plantations. Feces in the form of coffee beans that are still skinned horn with already dry conditions. The collection of stool taken home by workers farmer to his house and processed further for brewed. Since then, some farmers workers secretly enjoy civet coffee and sesame notify each other farmer workers [4].

One cause of civet coffee prices are high because of the taste and aroma typical, due to fermentation. The fermentation causes changes in the chemical components of the coffee beans as protein, caffeine and fat. Despite its high price, civet coffee production is limited because it depends on the animal population mongoose. Overcoming it is maintained civet several areas in Indonesia, especially in the mountain areas that have coffee plantations.

Civet are mammals which includes parts civet and mongoose (Viverridae). The scientific name is Paradoxurus hermaphroditus and in Malaysia known as civet sticky. Civet medium-bodied, with a total length of about $90 \mathrm{~cm}$ (including tail, about $40 \mathrm{~cm}$ or less) [2].

Civet has a simple organ of the digestive tract with a single stomach and intestine is relatively short. Mongoose produce gastric hydrochloric acid $(\mathrm{HCl})$ in large numbers, 
because the number of cells producing estate lot. Civet coffee is eaten by will experience a relatively short digestive process, so that only the skin is digested while the seeds are to be issued with feces. Because civet coffee just pick ripe red fruit, red and fresh, the civet coffee produced the best coffee. Civet coffee beans have a texture that is harder, but more brittle. This is presumably due to the digestive process involving protease enzymes in the gastric fluid (gastric juice) that alter the microstructure of coffee beans due to the breakdown of protein and lower levels of caffeine in it.

During this time at the ranch civet farmers normally give feed to each civet coffee berries ranged 1-3 kg/day. The amount of feed given is not all consumed mongoose. Until now there has been no regulation or standard amount of feed weight by age mongoose. Based on this research will be needed identification number of fruit consumption by age civet coffee. The research objective is to determine the level of consumption of the fruit civet civet coffee by age.

\section{MATERIALS AND METHODS}

\section{A. Place and Time}

The experiment was conducted in coffee plantations Pangalengan Pulo Sari Bandung regency. The research was conducted over 6 months from September 2013 to February 2014.

\section{B. Materials and tools}

The main material used in this experiment is the fruit of Arabica coffee varieties bourbon harvested from the coffee plantations Pulosari Pangalengan Bandung Regency with three levels of fruit maturity shown by three color indicator: a) skin coffee fruit is yellow, b) leather coffee berries red, c) skin red coffee berries blackish. In this experiment used 12 mongoose criteria: derived from Pangalengan Regency Bandung, type of weasel Pandan (Paradoxurus hermaphrodites), aged 1-2 years and 3-4 years old male and female. Body size with a total length of about $90 \mathrm{~cm}$ (including tail, $\pm 40 \mathrm{~cm}$ ).

\section{Method}

The principle of the welfare of animals used in this study is based on a five (5) the principle of freedom of animals (five freedom) which is applied as a minimum standard of animal welfare, the animal mongoose are involved in the production system civet coffee must be guaranteed wellbeing by applying the principles of animal welfare include: free from hunger and thirst; freedom from pain, injury and disease; freedom from discomfort, mistreatment, and abuse; free from fear and distress; and free to express their natural behavior.

The study was conducted to determine the number of pieces of civet coffee is selected from the three levels of maturity. This research was carried out in the field. The method used was completely randomized factorial design with 3 levels of treatment. The treatment of the first stage was the color of coffee cherries (W) consisting of 3 levels: the coffee fruit yellow (w1), red coffee cherries (w2) and blackish red coffee berries (w3). Treatment level to 2 is gender civet $(\mathrm{K})$ consisting of two levels: male mongoose (k1) and female mongoose (k2). Treatment level to 3 is the lifespan of civet (U) consists of 2 levels were age 1-2.

The study was conducted to determine the number of pieces of civet coffee is selected from the three levels of maturity. This research was carried out in the field. The method used was completely randomized factorial design with 3 levels of treatment. The treatment of the first stage was the color of coffee cherries (W) consisting of 3 levels: the coffee fruit yellow (w1), red coffee cherries (w2) and blackish red coffee berries (w3). Treatment level to 2 is gender civet $(\mathrm{K})$ consisting of two levels: male mongoose $(\mathrm{k} 1)$ and female mongoose $(\mathrm{k} 2)$. Treatment level to 3 is the lifespan of civet (U) consists of 2 levels were age 1-2 (u1) years and the age of 3-4 years (u2). Experiments were performed with three replications that consist of $3 \times 2 \times 2 \times 3$ $=36$ experimental units. In this experiment there were 12 treatment combinations as listed in Table 1.

TABLE I

TREATMENT COMBINATIONS COLOR MATRIX COFFEE Fruit, LEVEL AGE MONGOOSE

\begin{tabular}{|c|c|c|c|}
\hline $\begin{array}{c}\text { Coffee Fruit } \\
\text { Color }\end{array}$ & Gender & \multicolumn{2}{|c|}{ Age Mongoose (U) } \\
\hline$(\mathrm{W})$ & $(\mathrm{K})$ & $\mathrm{u}_{1}$ & $\mathrm{u}_{2}$ \\
\hline $\mathrm{w}_{1}$ & $\mathrm{k}_{1} \mathrm{~W}_{1}$ & $\mathrm{w}_{1} \mathrm{k}_{1} \mathrm{u}_{1}$ & $\mathrm{w}_{1} \mathrm{k}_{1} \mathrm{u}_{2}$ \\
\hline $\mathrm{w}_{1}$ & $\mathrm{k}_{2} \mathrm{~W}_{1}$ & $\mathrm{w}_{1} \mathrm{k}_{2} \mathrm{u}_{1}$ & $\mathrm{w}_{1} \mathrm{k}_{2} \mathrm{u}_{2}$ \\
\hline $\mathrm{w}_{2}$ & $\mathrm{k}_{1} \mathrm{~W}_{2}$ & $\mathrm{w}_{2} \mathrm{k}_{1} \mathrm{u}_{1}$ & $\mathrm{w}_{2} \mathrm{k}_{1} \mathrm{u}_{2}$ \\
\hline $\mathrm{W}_{2}$ & $\mathrm{k}_{2} \mathrm{~W}_{2}$ & $\mathrm{w}_{2} \mathrm{k}_{2} \mathrm{u}_{1}$ & $\mathrm{~W}_{2} \mathrm{k}_{2} \mathrm{u}_{2}$ \\
\hline $\mathrm{w}_{3}$ & $\mathrm{k}_{1} \mathrm{w}_{3}$ & $\mathrm{w}_{3} \mathrm{k}_{1} \mathrm{u}_{1}$ & $\mathrm{w}_{3} \mathrm{k}_{1} \mathrm{u}_{2}$ \\
\hline $\mathrm{w}_{3}$ & $\mathrm{k}_{2} \mathrm{~W}_{3}$ & $\mathrm{w}_{3} \mathrm{k}_{2} \mathrm{u}_{1}$ & $\mathrm{w}_{3} \mathrm{k}_{2} \mathrm{u}_{2}$ \\
\hline & & & \\
\hline
\end{tabular}

The linear model design used there as follows [3]:

Yijk $\quad=\mu+\mathrm{Ai}+\mathrm{Bj}+\mathrm{ABij}+\mathrm{Ck}+\mathrm{acik}+\mathrm{BCjk}+\mathrm{ABCijk}+\varepsilon(\mathrm{ijk})$

$\mathrm{Y} \_\mathrm{ijk} \quad=$ variable response due to the influence joint level $\mathrm{A}$ factor $\mathrm{i}, \mathrm{j}$ to the level of factor $\mathrm{B}$, and $\mathrm{C}$ level to $\mathrm{k}$ factors contained in the observation / treatment unit to $\mathrm{n}$.

$\mu \quad=$ average effects are real (constant value).

$\mathrm{A}_{\mathrm{i}} \quad=$ actual effect of the extent to $\mathrm{i}$ factor $\mathrm{A}$.

$\mathrm{B}_{\mathrm{j}} \quad=$ actual effect of the extent to $\mathrm{j}$ factor $\mathrm{B}$.

$\mathrm{AB}_{\mathrm{ij}} \quad=$ actual effect of the extent to $\mathrm{A}$ factor $\mathrm{B}$

$\mathrm{Ac}_{\mathrm{ik}} \quad=$ true effect of the interaction level to the level of a factor $\mathrm{i} \mathrm{k}$ factor to $\mathrm{C}$.

$\mathrm{BC}_{\mathrm{jk}}=$ true effect of the interaction of factor $\mathrm{B} \mathrm{j}$ level to the extent to $\mathrm{k}$ factor $\mathrm{C}$.

$\mathrm{ABC}_{\mathrm{ijk}} \quad=$ actual effect on the response variable is caused by the interaction between the level of the ith factor A, factor B $\mathrm{j}$ to the level and extent to $\mathrm{k}$ factor $\mathrm{C}$.

$\varepsilon$ (ijk) $\quad=$ the true effects to experimental unit $\mathrm{i}$ caused by the combination treatment (ijk).

Civet cultivated in one location. Civet maintained aged 1 year to 4 years. Care or maintenance performed in the civet cage. Each cage is filled by the tail. Mongoose maintenance is done by providing regular meals, bathing, vaccinating, cleaning cages and occasionally sprayed disinfectant in each cage. Every 2-3 days, mongoose fed ripe coffee fruit in the afternoon. On the next day the results fases seeds harvested in the form clots.

\section{Construction cage}

The model is individual and separate cages. shown in Figure 2. This animal is a cannibal. Between the cage and the other one wall made separately to avoid biting each others mongoose. Construction cage made of materials that are not easily broken and fragile, because the mongoose 
teeth are very sharp so as to damage the materials made of wood. On one side of the cage made of steel wire, iron wire, cage roof made of zinc. Cages equipped with places to eat and drink as well as a container to give milk. Besides the cage is also equipped with a bed placed in a higher angle and given the ladder, and has particularly water drains for easy cleaning.

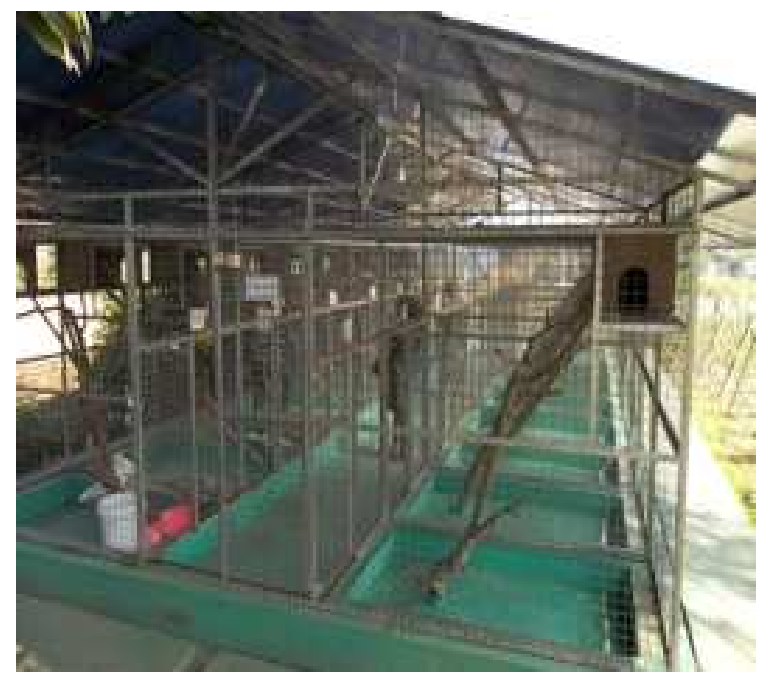

Fig. 1. Civet cages

Steps experiments include: (1) Sample preparation: coffee fruit consists of 3 levels of maturity, namely fruit coffee color yellow, red coffee berries and cherries dark red color. (2) The fruit of coffee each color is presented as much as 1.5 $\mathrm{kg}$ to male and female mongoose aged 1-2 years and 3-4 years; (3) Weighing the remaining amount of coffee cherries are eaten civet.

\section{RESULTS AND DISCUSSION}

Basically Luwak coffee is produced from civet civet are maintained according to the principles of animal welfare, can be maintained more quality than that produced from wild civet civet. This is because the animals are kept regularly medically examined, the feed can be controlled, as well as coffee issued with feces directly extracted and processed (ranging from washing to packaging) in a state still fresh. So in terms of food safety for consumers is maintained. While food security difficult in civet coffee obtained illegally.

Shape civet cages and feeding fruit to the civet coffee is shown in Figure 2. Luwak is the individual or separate, because these animals are cannibals (mutually prey). Coffee cherries are given in this study coffee berries yellow, red and black. Results of observation, coffee berries are eaten civet coffee fruit only red and black while the coffee fruit is not edible yellow mongoose.

Based on observations in the field can be seen characteristics female mongoose adalh have eight nipples, while the male mongoose has two eggs like a cat. According to a farmer in Pangalengan Bandung, Mr. Rudi, as well as breeding and business owners generally do mongoose captivity for breeding only do the media manufacture civet coffee and do their own breeding. Civet is obtained from the catch and bought from animal markets. The types of ferrets in their natural habitat has a small body size, about the size of a cat, except binturong. Civet Luwak has a body weight ranging from $1.3 \mathrm{~kg}$ to $5 \mathrm{~kg}$, body length of about $54 \mathrm{~cm}$ and length of tail almost the whole animal) body weight can reach $15 \mathrm{~kg}$. His body was covered with coarse fur is graybrown with black spots or stripes. Fur on the face, especially around the eyes and nose white mask with black lines between the eyes, and black on the muzzle, ears, lower legs, the tail end, and three rows of black lines in the hip area. Whereas in certain species have white fur over the eyes and the tip of the tail. Males and females have scent glands located around the anus (perineal gland) and emit a distinctive smell like the smell of pandan, so often called civet pandan. More developed scent glands in males Luwak, which is used in addition to communicating with the community, giving a signal to a female animal and mark the area of the territory.

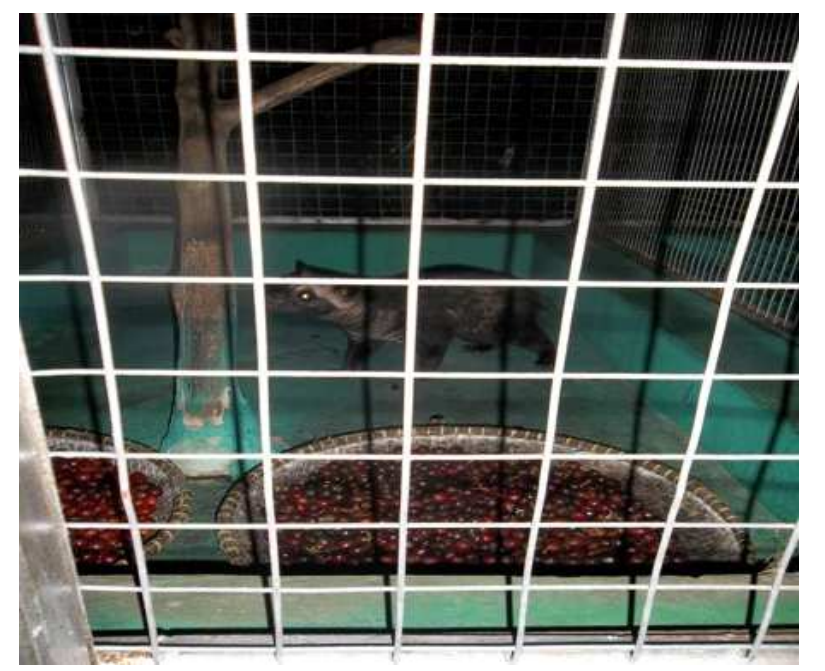

Fig 2. Provide to the civet coffee

Civet is a wild animal that has a habit of living in the wild. Civet deliberately maintained and used to produce food arranged civet coffee every day. Civet coffee is not consumed continuously from morning till night. Ripe coffee cherries are only given at night. As for the morning of civet given fruits such as bananas or papayas and to meet the protein needs of civet fed chicken, catfish and milk. Civet should be given vitamin supplements on a regular basis in order health awake [2].

The results showed that there are differences in the level of consumption of coffee fruit color red and burgundy are eaten civet based on age and gender. It can be seen from Table 2 and 3.

The observation of level of consumption of civet coffee berries as shown in Table 2 . The table shows that the rate of consumption of coffee berries are red and dark red. For male mongoose 2 years of age is approximately $(50.9 \%$ and $49.50 \%$ ) and civet females age 2 year was $(34.7 \%$ and $39.6 \%)$, whereas for male mongoose was 4 years old $(46.9 \%$ and $72.86 \%$ ) and civet females age 4 years $(55.9 \%$ and $84.86 \%)$.

Results of statistical analysis in Table 3 shows no difference in the level of consumption of red fruit for civet coffee 2 years old and 4 years old mongoose namely the age 
of 4 years (771.67) $\mathrm{g}$ higher than 2 years old mongoose (642.94) g. Differences in the level of consumption of coffee berries are dark red to civet age 2 years and 4 years old mongoose 4 years of age (1183.50) g higher than the age of 2 years mongoose $(668.89) \mathrm{g}$. It can be concluded that for civet terms of age both for coffee red or dark red color, civet age of 4 years higher than the level of consumption of civet age of 2 years.

TABLE II

Percentage Consumption Civet Age 2- 4 (Male and Female) FOR FRUIT

\begin{tabular}{|c|c|c|c|c|}
\hline \multirow{2}{*}{$\begin{array}{c}\text { Fruit } \\
\text { Color }\end{array}$} & \multicolumn{4}{|c|}{ Gender Mongoose-Age } \\
\cline { 2 - 5 } Red & Male -2th & Female -2th & Male- 4th & Female-4th \\
\hline & 764,6 & 521,6 & 704 & 839,6 \\
& $(50,9 \%)$ & $(34,7 \%)$ & $(46,9 \%)$ & $(55,9 \%)$ \\
\hline Burgundy & 742,6 & 595 & 1093 & 1273 \\
& $(49,50 \%)$ & $(39,6 \%)$ & $(72,86 \%)$ & $(84,86 \%)$ \\
\hline
\end{tabular}

TABLE III

RESUlts of Statistical ANALYSIS INTERACTION OF COLOR Fruit Civet COFFEE By Age AND GENDER INTERACTION WiTH AgE Mongoose

\begin{tabular}{|c|c|c|}
\hline \multirow{2}{*}{ Fruit Color } & \multicolumn{2}{|c|}{ Age Mongoose } \\
\cline { 2 - 3 } & 2 Years & 4 Years \\
\hline \multirow{2}{*}{ Red } & $642,94 \mathrm{a}$ & $771,67 \mathrm{~b}$ \\
& (a) & (b) \\
\hline Burgundy & $668,89 \mathrm{a}$ & $1183,50 \mathrm{a}$ \\
& (a) & (b) \\
\hline
\end{tabular}

Description: The letters in brackets to read the horizontal direction, comparing between $2 \mathrm{U}$ at the same $\mathrm{W}$

Lowercase without brackets readable vertical direction, Comparing between $2 \mathrm{~W}$ in the same $\mathrm{U}$

The letters in brackets to read the horizontal direction, comparing between $2 \mathrm{U}$ at the same $\mathrm{J}$

This is consistent with the statement that the nutrient needs for growth is strongly influenced by body weight and sex of the animal as well as the nation. Animal females usually has a faster growth rate than males, therefore, needs more energy for females than for males. Type the nation's major types of animals will require more energy than the nation's small animals [5].

Based on the statistical results in Table 3, the age of 2 years the level of consumption of civet coffee berries are red and dark red there is no difference. The level of consumption of civet age of 4 years for coffee cherries red and dark red there is a difference items, namely civet 4 years old consume more coffee berries are dark red.

Began civet civet coffee production after the age of one year and five months. Coffee delivery techniques are gradual. Usually an adult civet coffee is Able to produce as much as 300-1000 gram of feces Depending on the number of coffee that is eaten civet. Civet eating patterns must be arranged by changing the feed menu [1]. A diet for a mongoose should be varied and not always the coffee fruit. The goal is to keep the mongoose does not stress and metabolism in the stomach mongoose works well. If mongoose like certain fruits, give as much as possible. However, some time should be given Also meat and milk. In the case of feeding at night if the civet coffee is disliked by civet coffee berries replace them with new ones [4].
Interval feeding coffee cherries should be every two or three days. Fases mongoose can be harvested every two or three days. Number fases every day depending on the number of animals bred. If there are 30 tail mongoose, the timing of the harvest can be done every 10-tailed mongoose. In addition, the harvest can also be done in a certain time depending on the breeder as well mongoose. In order fases mongoose and civet coffee is produced optimal to do the following things: 1) processing of the harvest is done properly and well by adjusting the environmental conditions and climate, 2) the provision of coffee cherries are red after being washed beforehand, 3) rotation mongoose to produce coffee so that the continuity of fermentation in the stomach mongoose always maintained properly, 4) the cherries are given a minimum of two days [4].

A diet should be arranged in such a way by changing your diet every day. Any change depending on the results of observations of the behavior and habits of the mongoose. A diet for a mongoose should be varied and not always the coffee fruit. The goal is to keep the mongoose does not stress and metabolism in the stomach mongoose worked well. If the animal is like certain fruits, give as much as possible. Feeding at night if the coffee fruit looks already unpopular civet coffee cherries should be replaced new ones. Based on observations in the field of banana including civet favorite food that can be given at any time.

\section{CONCLUSIONS}

There are differences in the level of consumption of red fruit for civet coffee 2 years old and 4 years old mongoose namely the age of 4 years (771.67) $g$ higher than 2 years old mongoose (642.94) g. Differences in the level of consumption of coffee berries are dark red to civet age 2 years and 4 years old mongoose, the age 4 years of age (1183.50) $\mathrm{g}$ higher than the age of 2 years mongoose (668.89) g. Age 2 years the level of consumption of civet coffee berries are red and dark red there is no difference. The level of consumption of civet age of 4 years for coffee cherries red and dark red there is a difference items, namely civet 4 years old consume more coffee berries are dark red.

Differences in gender and age level mongoose effect on the amount of coffee consumed. Mongoose male gender higher consumption levels than female mongoose, civet age as well as older more feed civet coffee is needed compared to younger ones. High and low feed consumption in livestock are also affected by external factors (environmental) and internal factors (the condition of the animal itself).

\section{REFERENCES}

[1] Anggara, A dan Sri, M. 2011. Kopi Budidaya dan Pemasaran. Cahaya Atma Pustaka. Yogyakarta.

[2] Kurniawan, A. 2011. Meraup Untung dari Kopi Luwak. Klik Publishing. Yogyakarta.

[3] Mattjik, A.A. dan Sumertajaya, I.M. 2002, Perancangan Percobaan dengan Aplikasi SAS dan Minitab Jilid I, Bogor: IPB Press.

[4] Panggabean, E. 2011. Kopi Luwak. Agro Media Pustaka. Jakarta.

[5] Payne, J., C.M. Francis, K. Phillipps. dan S.N, Kartikasari. 2000. Panduan Lapangan Mamalia di Kalimantan, Sabah, Sarawak \& Brunei Darussalam. The Sabah Society, Wildlife Conservation Society-Indonesia Programme dan WWF Malaysia. ISBN 97995964-0-8. 